Research Journal of Applied Sciences, Engineering and Technology 17(1): 18-23, 2020

DOI: $10.19026 /$ rjaset.17.6030

ISSN: 2040-7459; e-ISSN: 2040-7467

(C) 2020 Maxwell Scientific Publication Corp.

Submitted: August 2, 2019

Accepted: November 6, 2019

Published: February 15, 2020

\title{
Research Article Research on Visual Transformation and Development of Huanglongfu Folklore
}

\author{
${ }^{1}$ Xiaowei Jiang and ${ }^{2}$ Sato Reika \\ ${ }^{1}$ Changchun University, Changchun 130022, China \\ ${ }^{2}$ Osaka Electrical Communication University, Osaka, Japan
}

\begin{abstract}
The research aims to discuss the ways of visual transformation and development of Huanglongfu folklore. From the perspective of cultural inheritance and innovation, the relationship between Huanglongfu folklore and visual transformation is analyzed. The ways to visualize Huanglongfu folklore are discussed combined with the practice of visual transformation of Huanglongfu folklore "Huangyujuan", so as to unlock the password of modern visual expression between the protection inheritance and the development utilization of Huanglongfu folklore. Visualizing Huanglongfu folklore is the effective means to solve the problem of its survival and development. It could visualize and develop Huanglongfu folklore by two kinds of ways of image presentation and animation presentation, which is of great significance to realize the rebirth of Huanglongfu folklore in the era of visual culture and to inherit and innovate the Huanglongfu culture.
\end{abstract}

Keywords: Cultural inheritance, folklore, Huanglongfu, Huangyujuan, visual transformation

\section{INTRODUCTION}

Huanglongfu, now Nong'an county, Changchun city, Jilin province, a bright pearl of northern China with rich historical and cultural accumulation, is one of China's famous historical cities, with a history of more than 7,000 years. As early as in the neolithic age, there were ancestors working, living and multiplying here. It is one of the birthplaces of Chinese civilization (Du, 2008). Although today Huanglongfu is just an ordinary small county, it is all-powerful several times in history. In the Han Dynasty, it was once the capital of Fuyu country; in the Sui Dynasty, it was the Fuyu city of Koguryo; in the Tang Dynasty, it was the Fuyu government of Bohai country; after Liao Dynasty destroyed Bohai country, it was renamed Huanglongfu (Dong, 2009). Fei Yue vowed to go straight to Huanglongfu and drank with other gentlemen (Zhao, 2007). "when we could drink in Huanglongfu", said Zhongshan Sun and "how we should drink in Huanglongfu and build the Chinese wind and rain building", said Dazhao Li. These above quotes all mention Huanglongfu and the Huanglongfu refers to Nong'an county (Song, 2015). According to the introduction of the comrade in charge of cultural relics institute of Nong'an county, Nong'an county not only has numerous unique Humanities creations, but also has many profound folk legends. These folk legends reflect people's love for life and reverence for nature. They are popular with people and are often spread around the world in oral form. From the content, Huanglongfu folk legends are closely related to the life culture, etiquette and customs of Huanglongfu people. In terms of subject matter, Huanglongfu folk legends not only include folk stories, myths and legends, religious stories, historical legends, but also include animal and plant stories, folk fables, love stories, philosophical stories and so on. These folk legends, with profound meanings, ups and downs of plots and rich fantasies, win universal praise (Chang and $\mathrm{Li}, 2014$ ).

As a kind of folk literature, folklore is an important part of intangible cultural heritage. Protecting and inheriting folk legends not only concerns the spiritual will and value orientation of a nation, but also is the historical mission entrusted by The Times and is the need of cultural transmission and cultural revival. Countries all over the world attach great importance to this study and our government also attaches great importance to it. The report of the $19^{\text {th }}$ national congress of the communist party of China clearly states that we should "strengthen the protection and utilization of cultural relics and the protection and inheritance of cultural heritage". Visualizing folklore is a feasible and only way to solve the problem of its survival and development. Under the influence of globalization and informatization, culture is entering a brand-new era of visual culture, that is, "the age of world images", as Martin Heidegger put it. The mode of human experience changes from words to vision and images. Against this background, folklore is facing a living state of either

Corresponding Author: Xiaowei Jiang, Changchun University, Changchun 130022, China, Tel.: +8615904430866

This work is licensed under a Creative Commons Attribution 4.0 International License (URL: http://creativecommons.org/licenses/by/4.0/). 
extinction or rebirth in visual form (Xu, 2012). As a small regional culture, Huanglongfu culture suffers from serious loss of folklore. Even some surviving legends are facing the dilemma of mutation or even extinction. Therefore, it is urgent to face up to the living state of Huanglongfu folklore, adapting to the changes and transform it from word language narrative form to visual image language narrative form as soon as possible, so as to realize the transformation of Huanglongfu folklore from language-driven culture to image-driven culture.

\section{CURRENT SITUATION OF THE DEVELOPMENT AND SPREAD OF FOLKLORE "HUANGYUJUAN"}

Many folk legends in Huanglongfu are not unfounded. Some have real objects and some have place names. "Huangyujuan" is a folk tale with place name (Hou, 2010). Huangyujuan is located in the northeast of Nong'an county, 60 kilometers away from the ancient city of Huanglongfu. It is a village subordinate to Nong'an county, as shown in Fig. 1. This place was rich in yellow croaker in Qing Dynasty and a pen was built here to raise yellow croaker in order to pay tribute to the emperor, so named Huangyujuan (meaning yellow croaker pen). Local folk legends about "Huangyujuan" in Nong'an county were mainly passed down by word of mouth and later scholars sorted out the legends into texts and handed them down (Chen, 2015). The legend of "Huangyujuan" is described in the "Historical Relics Record of Nong'an County". In addition, the scholar Shuhuai Hou and anonymous netizens have also described the legend of "Huangyujuan" in text form. At present, the legend of "Huangyujuan" is transmitted and communicated through oral, books and web forms, mainly by the two traditional ways of oral transmission and text presentation. The story synopsis of folklore "Huangyujuan": a long time ago, in close to the fish pen in the fishing village, there lived a man named $\mathrm{Er}$ $\mathrm{Ma}$, a vicious greedy fishing despot. He was to catch a magical yellow croaker with golden scales and jade wing to offer the emperor in order to obtain promotion knighted, so he ordered a young man named Lang Yu to catch the yellow croaker in seven days, otherwise the head of Lang Yu was to be used to sacrifice river. Kindhearted Lang Yu caught the yellow croaker, but he did not have the heart to give the yellow croaker to the fishing despot, so he let go of the yellow croaker. In that moment when the fishing despot prepared to chop down the head of Lang $\mathrm{Yu}$, the yellow croaker actively went up net and became a fairy, not only saving Lang $\mathrm{Yu}$, but also getting rid of the fishing despot. From then on people lived in peace and contentment, living on good days.

The legend "Huangyujuan" is a classic tale of rewarding virtue and punishing vice, widely known in the past. It is one of the well-known folk legends of

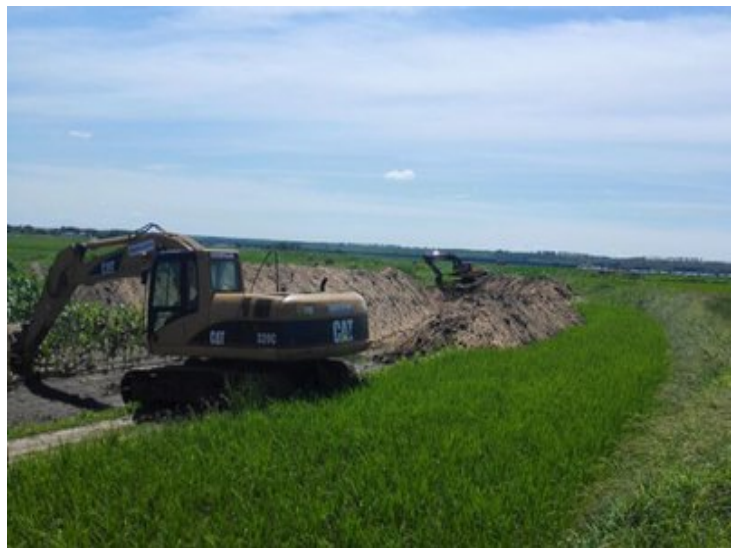

Fig. 1: The village of Huangyujuan

Huanglongfu, reflecting the character of the Huanglongfu people who are not afraid of violence and sacrifice and deeply inspiring people to be brave and kind. This legend also tells people that as long as you have kindness in mind and having high ambition, heavy friendship, boldness and decisiveness, anybody can be overcome. Such a classic inspirational story is little known at present and even close to extinction. The reason is that the existence form and transmission path of "Huangyujuan" legend are still two traditional ways of oral inheritance and text presentation, which are obviously in conflict with the intuitive, vivid, visual, interactive, multi-dimensional cognition and thinking in the visual culture background (Wang, 2016), thus affecting its development and communication. Under the background of informatization and digitization, people's traditional production and life style and environment have undergone great changes and the inheritance mode and context to which folk legends are attached have also changed naturally. The world is entering the world of a visual image, so any perception of culture and art, understanding and interpretation cannot leave the visual expression of image. Visual images are intuitive, vivid and easy to understand, compared with text and voice more to cause the audience's attention in a short time and are not subject to the effects of different nationality, region, nation, language, culture and customs, easier to spread and exchange (Tan and Zheng, 2016). Folklore will be bound to be annihilated if it can't be converted into image. At present, visual culture and its communication based on images have a great impact on the process of human civilization on a global scale (Wang, 2016). Therefore, it is urgent to adapt to the development and changes of The Times, update ideas and visually transform and develop the folk legends of Huanglongfu as soon as possible, so as to make its excellent cultural essence form a powerful social effect.

\section{MATERIALS AND METHODS}




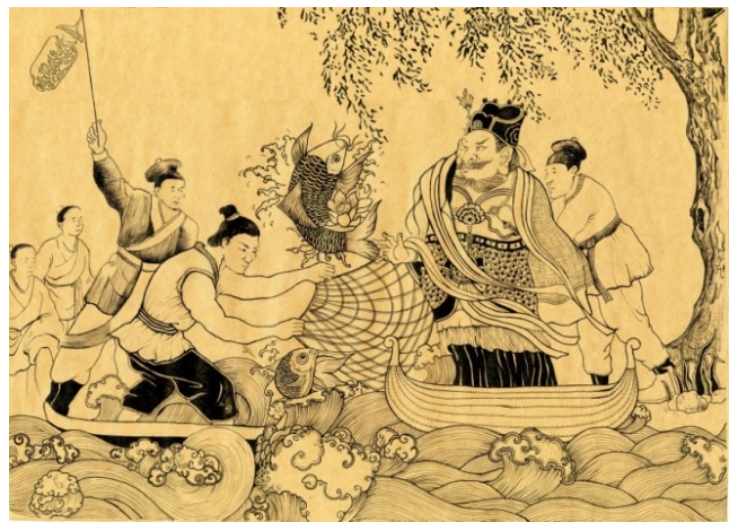

Fig. 2: Visual image of the fishing despot and the yellow croaker (Hui Yang)

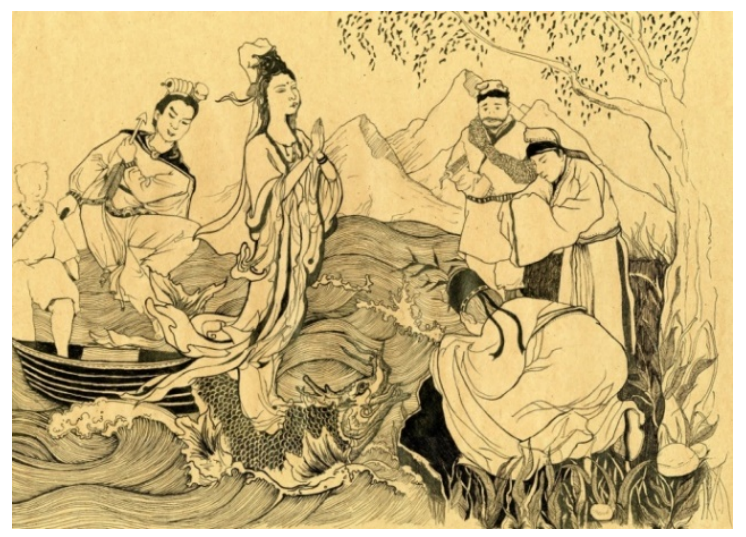

Fig. 3: Visual image of the yellow croaker fairy (Hui Yang)

It is an inevitable choice of solving its survival problem and an effective way of promoting its development to visually transform Huanglongfu folklore lost seriously, displaying it with visual image. According to the manner of visual expression, the folk legends of Huanglongfu can be visually transformed and developed in the following two ways.

Way of image presentation: Presenting folklore with image refers to converting the figures described in legends into the visual modeling (Jun, 2012), transforming the language and words into the visual images, namely presenting the content or spiritual connotation of legends with intuitive visual images to make them visual and vivid, with thoughts, souls and vitality, so as to gain understanding and interaction based on the visual consensus of images (Liu, 2014). With image as the carrier to visually transform Huanglongfu folklore has the strong visual continuity and visual emotion (Zhang, 2018), which can improve people's awareness and attention to it, so as to effectively protect and inherit Huanglongfu folklore. In the process of visual transformation, it needs attend that the images created not only should have cultural flavor and artistic charm, but also have clear meaning and can reflect the national temperament and cultural connotation of legends, which needs carefully extract the description of figures from legends and highly generalize and process to create vivid visual images that can realize the emotional docking between people and folklore. The creation of visual images of folklore "Huangyujuan" needs to explore the natural landscape, historical culture and humanistic folk customs of generating folklore "Huangyujuan" in a reasonable context, after that, carry out artistic processing and creation and reproduction of the figures described in the legend. The key is to grasp the national spirit and historical features of "Huangyujuan" folklore, so as to create visual images with distinct cultural connotation and unique artistic style and then better convey the unique value and significance of this legend.

In the creation, it should use the most concise image to convey the rich content of "Huangyujuan" folklore. However the content to express is often many, so it have to refine the typical figure as a creative source point and then expand and extend. It could take the hero described in the legend as the main body of creation and also could use the connotation of the legend to create, so as to eventually make the visual image of the legend not only have beauty on the surface, but also have profound meaning; not only fully reappear the people and things in the legend, but also organically integrate the soul and national spirit of the legend; not only have strong visual impact, but also have strong appeal, making audience arouse related association and form the emotional interaction.

Firstly, it is necessary to investigate and research the human environment, geographical features, historical period and other aspects described in the legend "Huangyujuan" as the basis and starting point of creation. Secondly, it should generalize and summarize the material obtained by investigation as a breakthrough of creation. There are many images in legend "Huangyujuan" that can be used as creative source points, such as the image of cruel and greedy fishing despot Er Ma, the image of yellow croaker fairy of jade appearance, the image of good-hearted Lang Yu and so on. Selecting the image Er Ma to refine and create and integrating into the dynamic image of the yellow croaker actively going up net can not only show the main content of the legend "Huangyujuan", but also convey the bravery national integrity, as shown in Fig. 2. Choosing the sacred image of the yellow croaker fairy to extract and create and integrating the image of Lang $\mathrm{Yu}$ and the image of the people coming to thank can not only reflect the dominant idea of the legend, but also render the legendary color of the story, as shown in Fig. 3. Thirdly, it should embody the investigation and conception, using the aesthetic knowledge and the artist's creative ability to present the conceived image with the line art form of having Chinese artistic charm. Finally, it should carry out color performance. Color has emotional and symbolic significance and could 
Res. J. App. Sci. Eng. Technol., 17(1): 18-23, 2020

Table 1: Main subjects provided by Huanglongfu folklore for animation creation

\begin{tabular}{|c|c|c|c|c|c|c|c|c|}
\hline Myths legen & nds & Religious stories & Folk stories & $\begin{array}{l}\text { Historical event } \\
\text { legends }\end{array}$ & $\begin{array}{l}\text { Plant and animal } \\
\text { stories }\end{array}$ & Folk fables & Love stories & $\begin{array}{l}\text { Philosophic } \\
\text { stories }\end{array}$ \\
\hline $\begin{array}{l}\text { Liao } \\
\text { legend } \\
\text { Nong'an }\end{array}$ & $\begin{array}{r}\text { tower } \\
\text { of }\end{array}$ & $\begin{array}{l}\text { Huanglong } \\
\text { temple legend }\end{array}$ & $\begin{array}{l}\text { Sprinkling } \\
\text { dragon and } \\
\text { threading } \\
\text { dragon's tail }\end{array}$ & $\begin{array}{l}\text { Springnabo and } \\
\text { Pledging } \\
\text { inscription }\end{array}$ & $\begin{array}{l}\text { Why dog feuding } \\
\text { with cat }\end{array}$ & Huangyujuan & $\begin{array}{l}\text { Stone human and } \\
\text { doctor }\end{array}$ & Fulongquan \\
\hline $\begin{array}{l}\text { Wanjin } \\
\text { legend }\end{array}$ & tower & $\begin{array}{l}\text { God water of } \\
\text { Shuangquan } \\
\text { temple }\end{array}$ & $\begin{array}{lr}\begin{array}{l}\text { Hanging } \\
\text { gourd }\end{array} & \text { and } \\
\text { inserting } & \\
\text { mugwort } & \text { in } \\
\text { Dragon } & \text { Boat } \\
\text { Festival } & \end{array}$ & $\begin{array}{l}\text { Fei Yue vowing } \\
\text { to fight } \\
\text { Huanglongfu }\end{array}$ & $\begin{array}{l}\text { Rabbit tail being } \\
\text { not long }\end{array}$ & $\begin{array}{l}\text { Huanglong tower } \\
\text { and small golden } \\
\text { horse }\end{array}$ & $\begin{array}{l}\text { Testing son-in- } \\
\text { law }\end{array}$ & Immortal grass \\
\hline $\begin{array}{l}\text { White } \\
\text { stream }\end{array}$ & sand & & $\begin{array}{l}\text { Origin of eating } \\
\text { eel }\end{array}$ & $\begin{array}{ll}\text { Origin } & \text { of } \\
\text { Huanxiling }\end{array}$ & $\begin{array}{l}\text { Calystegia } \\
\text { hederacea }\end{array}$ & $\begin{array}{l}\text { Copper heart and } \\
\text { iron bladder }\end{array}$ & $\begin{array}{l}\text { Legend of Kang } \\
\text { fairy } \mathrm{Yu}\end{array}$ & Smelly girl \\
\hline $\begin{array}{l}\text { Mending } \\
\text { stuff } \\
\text { cramps }\end{array}$ & $\begin{array}{r}\text { big } \\
\text { with }\end{array}$ & & $\begin{array}{l}\text { Origin legend of } \\
\text { the name Halahai }\end{array}$ & $\begin{array}{l}\text { A gush of } \\
\text { precious spring }\end{array}$ & $\begin{array}{l}\text { Scalper saving } \\
\text { his master }\end{array}$ & Huashicao & $\begin{array}{l}\text { Bees and } \\
\text { buckwheat }\end{array}$ & $\begin{array}{l}\text { Meeting } \\
\text { beautiful } \\
\text { woman When } \\
\text { the bad luck }\end{array}$ \\
\hline $\begin{array}{l}\text { First male } \\
\text { first female }\end{array}$ & and & & $\begin{array}{l}\text { Zhapengke and } \\
\text { Mazhacai }\end{array}$ & $\begin{array}{l}\text { The light of god } \\
\text { wax }\end{array}$ & $\begin{array}{l}\text { Origin of red } \\
\text { mushroom niang }\end{array}$ & No one escaping & $\begin{array}{l}\text { Origin } \\
\text { comparing } \\
\text { cncondom } \\
\text { loving people }\end{array}$ & God bird \\
\hline $\begin{array}{l}\text { Heron } \\
\text { osprey }\end{array}$ & and & & & \begin{tabular}{lr} 
Place & name \\
origin & of \\
previous & Bajilei \\
\multicolumn{2}{l}{ of Nong'an }
\end{tabular} & Legend of Wula & $\begin{array}{l}\text { A jar of gold } \\
\text { ingot }\end{array}$ & $\begin{array}{l}\text { Wushu and } \\
\text { Yingge }\end{array}$ & $\begin{array}{l}\text { Place name } \\
\text { origin of } \\
\text { Yuanbaowa of } \\
\text { Nong'an }\end{array}$ \\
\hline
\end{tabular}

enhance the expression of theme connotation, influencing people's mood and making people produce different psychological associations. For this reason, the black, white and gray of achromatic color that are the symbol of eternity and firmness are chosen as the main colors to convey the profound implication of infinite meaning, which is closely related to the moral of the legend and shows the historical and cultural nature of the legend. Although the achromatic color is not gorgeous and beautiful, it is eye-catching, symbolizing the vigorous development momentum of the legend "Huangyujuan", which contains the meaning of cultural inheritance and innovation (Zhao and Gao, 2018). The two visual images vividly convey the unique value and profound connotation of the legend "Huangyujuan" of Huanglongfu, which is conducive to the dissemination and communication of the legend.

Way of animation presentation: The animation that gives life to the created objects and makes the objects alive in the picture is the link between the protection and inheritance and the exploitation and utilization of Huanglongfu folklore (Wang et al., 2013). As the country puts forward the requirement of telling its own stories well and pays more and more attention to cultural confidence, more and more folk tales are used to create animations, which has the property of protection and inheritance and is a kind of productive protection (Zhao, 2014) and a practical and feasible way of living inheritance of folk tales (Zhao and Zhang, 2017).

Huanglongfu has many folk legends of which the connotation is profound and the value is unique. These folk legends could provide animation creation with many themes, such as myths legends, religious stories, folk stories, historical event legends, plant and animal stories, folk fable, love story, philosophic story, etc., as shown in Table 1. All these themes could be used as a source of animation creation. The animation creation of the legend "Huangyujuan" could mine and extract the image of characters and objects and the cultural environment and geographical features described in the legend to create an intuitive and vivid dynamic image, so as to make the conveyed story content more visual and vivid. In creation, scenes, characters and plot design are just as important. Story plot is extracted from the legend, discarding the dross and selecting the essential, extracting exciting plot structure, all linked with one another and the structure is rigorous. The refinement of the scenario first establishes the monism of the theme of Lang $\mathrm{Yu}$ fishing and then on this basis, gradually sets the specific plots of the kind-hearted Lang Yu releasing the yellow croaker, the fishing despot preparing to cut the head of Lang Yu, the yellow croaker actively going up net and becoming a fairy, the yellow croaker fairy saving Lang $\mathrm{Yu}$ and getting rid of the fishing despot and the people coming to thank the grace of yellow croaker fairy. These plots could make audience produce visual experience of feeling, memory and imagination, entering the associative space and time of recalling a long history and culture and forming emotional communication. Such animation works can not only reflect the cultural connotation and value, but also not lose the modern sense and nationality. They are the reverence for the folk traditional culture, which will be very valuable, because it can enable the audience to harvest the folk history knowledge and feel the national spirit in the process of watching, which will be the best inheritance to Huanglongfu folklore and also an effective measure to promote the sustainable development of the economy society.

\section{RESULTS AND DISCUSSION}

The precious folk legends of Huanglongfu are the cultural achievements and wisdom crystallization created by the people of Huanglongfu in previous dynasties. They not only contain the password to 
unlock the ancient Chinese civilization, but also are the source of inspiration for modern design and creation. However, in the modern society where visual culture prevails, "seeing" has gradually become the most important way to grasp the world. The language-driven culture is transforming to image-driven culture, with images becoming the "leading role" and languages relegated to the "supporting role" and images showing a tendency of overwhelming languages (Yu, 2015). This situation brings great crisis to the living state of folklore and at the same time also provides opportunities and challenges for it to achieve great development. Under such background, it is urgent and necessary to visually transform Huanglongfu folklore.

The visual transformation of folklore means realizing the media transformation of folklore by means of visual images, that is using visual way to creatively express the content and thought essence of folklore in a visual way, so as to be easy to perceive, understand and remember and meet people's visual aesthetic needs. Specifically speaking, it refers to adopting graphics, image, shape, color, structure, space, material and other basic visual elements to creatively visually transform the specific content, cultural spirit or temperament characteristic of legend, in order to achieve the purpose of effective communication, realizing the expression and spread through visual language and making use of the form of "seeing" to communicate, across the language barrier. The visual transformation of Huanglongfu folklore is to adopt images and other visual elements to make creative expression of Huanglongfu folklore in line with modern visual characteristics, so as to regenerate it in visual form, thus conforming to people's intuitive, visual and multidimensional cognitive and thinking mode under the background of visual culture. Its core lies in innovating the presentation mode of Huanglongfu folklore to be suitable for modern people's production and living environment and manner, so as to get effective communication and better inheritance and innovation of Huanglongfu folklore. Most folk legends are constructed by means of historical expression and literary expression to express a kind of spirit, a kind of value or to explain a kind of local scenery or custom. Only by using abstract logical thinking to summarize, judge and reason can the cognition and understanding of legends be obtained, while innovative visual transformation and visual expression of legends with image can help the audience form cognition in a short time and generate deep impression, which is more conducive to the communication and innovative use of folklore.

The visual transformation of folk legends should pay attention to the expression of cultural connotation. During the transformation process, attention should be paid to displaying the historical background and cultural features of legends, as well as the rational application of art style, so as to enhance the artistic quality of visual legends.

In summary, it could visualize and develop Huanglongfu folklore by two kinds of ways of image presentation and animation presentation, which is of great significance to realize the rebirth of Huanglongfu folklore in the era of visual culture and to inherit and innovate the Huanglongfu culture.

\section{CONCLUSION}

The folk legend "Huangyujuan" reflects the strong and brave character of Huanglongfu people who are not afraid of sacrifice. It is not only the "living fossil" of Huanglongfu culture, but also the lifeblood of continuing the national spirit, will and value orientation. As a native of Huanglongfu, it should not stay aloof from the loss of hometown culture, but should inherit and innovate hometown culture, which is my duty. Through visually transforming the "Huangyujuan" legend, it not only could improve people's perception of its cultural connotation, but also could effectively educate social members, which is of great significance and far-reaching. Visually transforming Huanglongfu folk legends is based on cultural inheritance and innovation, with the help of the power of the visual elements, realizing the intuitive, visual and interactive multidimensional display, so as to make them shine brightly in the era of visual culture and realize the contemporary value of Huanglongfu culture, providing guidance for the revival of Chinese culture and local economic and cultural strategies.

\section{ACKNOWLEDGMENT}

This research is supported by the Art Project of 2019 National Social Science Foundation under the grant No. 19BH148. This research is also supported by the Thirteenth Five-Year Social Science Project of Education Department of Jilin Province under the grant No. JJKH20170503SK. This research is also supported by the Science Research Cultivation Project of Changchun University under the grant No. SKC201909.

\section{CONFLICT OF INTEREST}

We declare that we do not have any commercial or associative interest that represents a conflict of interest in connection with the work submitted. The results are not related to previous findings.

\section{REFERENCES}

Chang, Y. and X. Li, 2014. Advantages and values of animation art in spreading Miao folk tales in Guizhou. Beauty Times, 1: 106-107.

Chen, X., 2015. The exploration of animation image on the adaptated from Fuzhou folk legend. Fujian Normal University, Fuzhou, 5(25): 45-52. 
Dong, X., 2009. Huanglongfu $\bullet$ Ancient Pagoda $\bullet$ Nong'an: Origin of place name of Nong'an county in Jilin Province. China Place Name, 2: 5960.

Du, Y., 2008. Rise and fall evolution of Huanglongfu. Northeast Normal Univ., Changchun, 6(9): 2-20.

Hou, S., 2010. Witness of Liao Tower: Literary Description of Huanglongfu Culture. Jilin Literature and History Press, Changchun.

Jun, X., 2012. The modern visual transformation of literature in nomadism civilization: The comprehension on the contemporary prairie painting. Inner Mongolia University, Hohhot, 5(6): 15-23.

Liu, F., 2014. Cultural symbols and the study of the spread of intangible cultural heritage. Dongyue Thesis, 35(7): 147-150.

Song, H., 2015. Visit to Huanglongfu. Qiaoyuan, 1: 46.

Tan, Y. and J. Zheng, 2016. News Editing. Huazhong University of Science and Technology Press, Wuhan.

Wang, L., Y. Wu and H. Ma, 2013. Techniques for Preproduction of Animated Short Films. China Textile Press, Beijing.

Wang, Y., 2016. Study on the transformation of traditional art resources under the background of visual culture: A case of Dazu stone carving in Chongqing. Local Art Res., 5: 62.
$\mathrm{Xu}, \mathrm{X}$., 2012. Discussion on the visual transformation problem of Dunhuang cultural and artistic resources in the global Era. The Silk Road, 14: 1921.

$\mathrm{Yu}, \mathrm{H} ., 2015$. Landscape production and landscape narrative: Centered on the legend of the white snake. East China Normal University, Shanghai, 5(1): 5-23.

Zhang, A., 2018. Visual design translation of intangible cultural heritage. Packag. Eng., 39(20): 121-125.

Zhao, D., 2014. Research on the being digital protection and development of historical cultural resourceswith Shanxi as the center. Shandong Univ., Jinan, 4(10): 191-217.

Zhao, H. and J. Gao, 2018. Never abandon the essence: Study on Yi nationality pattern innovation and inheritance method. Art Design, 9: 130-131.

Zhao, J. and N. Zhang, 2017. Product packaging design based on intangible cultural heritage of Tianjin coastal area. Packag. Eng., 38(12): 65-68.

Zhao, Y., 2007. Huanglongfu during the Liao and Jin Dynasties. Northern Cultural Relics, 1: 69-76. 